\title{
PERANAN BAHAN HIJ AUAN TANAMAN DALAM PENINGKATAN BAHAN ORGANIK DAN STABILITAS AGGREGAT TANAH ULTISOL LIMAU MANIS YANG DITANAMI JAGUNG (Zea mays L.)
}

\author{
Yulnafatmawita, Amrizal Saidi, Gusnidar, Adrinal, dan Suyoko \\ F akultas Pertanian U niversitas Andalas Padang
}

\begin{abstract}
A research aiming to improve soil aggregate stability of Ultisol in terms of creating sustainable agriculture and environmental development was conducted by applying fresh organic matter $(\mathrm{OM})$ into soil. Three types of OM sources used were Titonia diversifolia, Chromolaena odorata, dan Gliricidia sepium. This research was conducted in Ultisol Limau Manis Sumbar having annual rainfall $>5000 \mathrm{~mm}$, in 2008. The fresh OM used was cut, mixed with soil up to $20 \mathrm{~cm}$ depth, and then incubated for approximately one month before corn seeds were planted. Soil was sampled before being treated with OM and then after harvesting corn (4 moths after applying OM). Soil OM content as well as soil aggregate stability (AS) and several other soil physical properties wer analysed in laboratory. The results showed that soil OM content and AS increased after one planting period. Besides that, soil physical properties were also improved. As soil physical properties became better, corn production was also higher at plot with than without OM application. Among 3 species of OM added, Tithonia diversifolia gave highest corn biomass. Level of land slope (0-8\% dan 15-30\%) did not show significant difference either for biomass or for soil OM content and soil AS.
\end{abstract}

Key Words: marginal soil, green manure, soil aggregate stability, soil organic matter

\section{PENDAHULUAN}

Pemantapan aggregat tanah sangat penting untuk meningkatkan laju infiltrasi dalam usaha mengantisipasi terjadinya aliran air di permukaan tanah (runoff) yang menyebabkan terjadinya erosi. Di samping itu, tanah dengan struktur yang ideal mempunyai kandungan air dan udara tanah yang seimbang. Kondisi demikian akan mengoptimalkan kehidupan biologis tanah serta akan mengefisienkan atau memaksimalkan ketersediaan dan penyerapan hara oleh tanaman. Aggregat yang mantap bisa diperoleh dengan bantuan bahan organik (BO) sebagai agen pengikat butir tanah.

Aggregat tanah yang terjadi dengan bantuan agen pengikat BO akan lebih stabil, terutama bila terjadi pembasahan secara tiba-tiba. Hal ini sangat dibutuhkan bagi tanah-tanah di daerah super basah seperti di Sumbar khususnya kota Padang. Aggregat yang mantap mampu mempertahankan bentuk dan ukurannya ketika menerima pukulan butir hujan ataupun energi luar lainnya. Oleh sebab itu, tanah dengan aggregat yang mantap akan mampu melewatkan air ke dalam profil tanah dan mengurangi aliran permukaan secara berkesinambungan.

Akan tetapi, tanah di daerah tropis super basah ini umumnya mempunyai kandungan BO yang rendah, karena tingginya laju dekomposisi BO akibat suhu dan curah hujan $(\mathrm{CH})$ yang tinggi. Di samping itu, BO juga akan mengalami dekomposisi dan mineralisasi dengan waktu dan managemen yang diberikan pada suatu lahan. Laju perombakan BO akan semakin intensif bila BO tersebut terekpos ke udara bebas dan terjangkau oleh mikroba perombak seperti akibat pengolahan tanah.

Pengolahan tanah yang intensif umumnya dilakukan untuk pertanian tanaman semusim, khususnya serealia dan hortikultura di Sumatra Barat. Petani menganggap bahwa persiapan lahan yang baik adalah dengan mengolah tanah sehalus dan segembur mungkin serta membuang semua sisa tanaman dari lahan dan membakarnya. Mereka tidak mempedulikan cara pengolahan tanah yang tegak lurus kontur dan tanpa teras atau pagar lorong pada tanah berlereng. Pengembalian BO setelah panen ke lahan juga hampir tidak 
dilakukan, melainkan dibakar. Lahan gembur akibat pengolahan memang menguntungkan bagi pertumbuhan tanaman awal, tetapi hanya dalam jangka pendek. Dalam jangka panjang, pengolahan tanah yang intensif akan menyebabkan menipisnya cadangan BO tanah dalam waktu singkat, yang mengakibatkan degradasi lahan dan menurunnya kualitas tanah dan akhirnya lingkungan.

Laju kehilangan BO tanah di Sumatra Barat, khususnya kota Padang yang menerima $\mathrm{CH}$ cukup tinggi > 5000 $\mathrm{mm} /$ tahun (Rasyidin, 1994) seperti di daerah gunung Gadut dan sekitarnya, sangat cepat. Lahan di daerah Limau Manis, kaki bagian bawah (lower footslope) G.Gadut yang berada pada ketinggian $\pm 250 \mathrm{~m}$ dpl ini di dominasi oleh tanah berordo Ultisol dengan morfologi berombak sampai berbukit. Lahan ini sangat peka terhadap erosi, karena umumnya mempunyai kelas lereng > $15 \%$ (tidak disarankan lagi untuk tanaman semusim), namun masih diolah secara intensif oleh penduduk demi pemenuhan kebutuhan hidup mereka. Tidak heran, kalau setiap hujan terlihat air sungai menjadi kuning akibat tanah tererosi dari ordo Ultisol. Bahkan, bila hujan terjadi seharian telah menimbulkan banjir di kota Padang, walaupun tidak bertahan lama.

Dalam usaha mengantisipasi bencana alam yang lebih besar, khususnya di kota Padang, dan untuk mempertahankan produktifitas lahan secara berkelanjutan, maka perlu dilakukan usaha perbaikan sifat fisika tanah melalui peningkatan kandungan BO tanah. Hal ini bisa dilakukan dengan pengurangan laju dekomposisi $\mathrm{BO}$ melalui pengurangan intensitas pengolahan tanah serta dengan penambahan BO secara berkala Pengurangan intensitas pengolahan tanah berarti penguran frekuensi pelonggaran dan pemecahan aggregat tanah, sekaligus pengurangan aktifitas jasad renik tanah. Sedangkan pengurangan intensifitas pengolahan dimaksudkan untuk mengolah tanah seperlunya, cukup untuk menjamin pertumbuhan tanaman awal, atau dikenal pengolahan tanah minimum, seperti pengolahan dalam strip, tanpa pengolahan tanah, dan sebagainya. Hal ini bukan saja dapat mengurangi oksidasi BO tanah, tetapi juga dapat mengurangi biaya tenaga kerja atau ongkos produksi.

Sumber BO yang digunakan pada penelitian ini dikenal juga sebagai pupuk hijau. Penggunaan jenis BO ini didasarkan karena pupuk hijau bisa diproduksi lansung atau ditanam disekitar lahan pertanaman, jadi tidak memerlukan biaya transportasi untuk membawa ke areal pertanaman. Di samping itu, pupuk hijau juga dapat tumbuh dan bertahan di lahan marginal. Ada beberapa jenis pupuk hijau yang dapat tumbuh di lahan miskin hara dan selama ini sudah banyak digunakan untuk kontribusi haranya bagi pertumbuhan tanaman, seperti Sesbania, Leucaena, dan Gliricidia (Burhan et al., 1996), Tithonia (Hakim et al., 2006; Gusnidar, 2007), Chromolaena (Jamilah, 2006), dan banyak lagi yang lain.

Pada peneitian ini digunakan tanaman jagung (Zea mays) sebagai indikator. Jagung merupakan tanaman palawija yang biasa dipanen sekitar umur 3.5 bulan. Persiapan lahan untuk pertanaman jagung ini umumnya dengan cara mengolah tanah secara intensif, aggregat tanah sampai halus dan bersih dari gulma, BO atau sisa panen. Ketika tanaman dipanen, tanah akan terbuka. Dengan kondisi lahan yang pada umumnya berlereng, curah hujan yang tinggi akan menyebabkan resiko terjadinya erosi sangat besar. Oleh sebab itu, perlu peningkatan kandungan BO agar stabilitas aggregat tanah menjadi stabil dan kemungkinan terjadinya erosi bisa diminimaisir.

Bertitik tolak dari masalah yang dikemukakan diatas, maka dilakukan penelitian pemanfaatan bahan organik segar untuk mengantisipasi masalah yang akan mungkin timbul. Penelitian ini bertujuan untuk mengevaluasi pengaruh pemberian BO segar bagi peningkatan kadar BO dan stabilitas aggregat tanah Ultisol Limau Manis.

\section{BAHAN DAN METODA}

Penelitian ini merupakan penelitian lapangan dan laboratorium. Percobaan lapangan dilkukan pada Ultisol Limau Manis Padang pada dua kelas lereng 3\% (0$8 \%$ ) dan $15-30 \%$ (25\%). Tiga jenis bahan organik segar yang digunakan yaitu 
Chromolaena odorata, Gliricidia sepium, dan Tithonia diversifolia dipotong-potong dan dicampurkan ke dalam tanah sedalam 20 $\mathrm{cm}$ pada masing-masing plot, lalu diinkubasikan selama 1 bulan. Tanah dipertahankan lembab selama inkubasi BO dengan menyiram plot setiap hari bila hari tidak hujan. Di samping itu, tanah juga diberi kapur untuk mengurangi kejenuhan $\mathrm{Al}$ yang tinggi pada Ultisol ini (Hakim dan Agustian, 2005).

Setelah inkubasi berakhir, dimana bahan organik yang ditambahkan sudah melapuk, benih jagung ditugal dengan jarak $20 \times 80 \mathrm{~cm}$, sehingga masing-masing plot (2 x $2 \mathrm{~m}$ ) terdapat 30 rumpun tanaman. Benih jagung yang digunakan yaitu BISI-2. Selama pertumbuhan, tanaman jagung disiram jika hari tidak hujan, kemudian juga diberi pupuk buatan sesuai rekomendasi untuk menjamin pertumbuhan tanaman. Tanaman dipanen pada umur 80 hari, untuk menghitung biomasa tanaman pada saat pertumbuhan vegetatif sudah mencapai maksimum.

Sampel tanah utuh dan terganggu diambil dari plot percobaan sebelum pemberian perlakuan dan setelah panen jagung. Sampel tanah utuh diambil untuk anaisis BV, TRP, dan Permeailitas tanah, sampel tanah terganggu untuk analisis tekstur, BO, serta sampel beraggregat utuh untuk analisis stabilitas aggregate tanah. Analisis tanah dilakukan di laboratorium Ilmu Tanah Fakultas Pertanian Universitas Andalas Padang. Sampel tanah dikeringanginkan sampai kadar air $<20 \%$, lalu dihaluskan sesuai kebutuhan dan disimpan dalam kemasan tertutup setelah diberi label. Analisis C-organik dengan metoda Walkley dan Black, BV dan TRP dengan Gravimetri, permeabilitas tanah dengan metoda Constant head water table, serta stabilitas aggregat dengan ayakan kering dan basah.

\section{HASIL DAN PEMBAHASAN}

\section{Situasi Daerah Penelitian}

Daerah penelitian terletak di Nagari limau Manis Kecamatan Pauh Kota Padang Propinsi Sumatera Barat, yang umumnya menerima curah hujan yang tinggi setiap tahunnya. Posisi daerah penelitian secara geografis berada pada $100^{\circ} 27^{\prime} 46.5^{\prime \prime}$ BT dan $00^{\circ}$ 54'28.2" LS dengan ketinggian $276 \mathrm{~m}$ dpl. Peta lokasi penelitian ditampilkan pada Gambar 1. Daerah limau Manis merupakan kipas kolluvium yang terletak di kaki Gunung Gadut. Bahan induk tanah berasal dari tuff pumice yang bersifat masam.

Curah hujan tahunan di Limau Manis Padang, rata-rata berkisar 5000 $\mathrm{mm} / \mathrm{tahun}$. Menurut klassifikasi iklim oleh Schmidt dan Ferguson daerah ini termasuk daerah beriklim tipe A atau basah Selain mahasiswa dan karyawan Universitas Andalas yang berdomisili di Limau Manis, penduduk asli daerah ini pada umumnya adalah petani tradisional dengan taraf pendidikan yang rendah. Demikian juga pada umumnya petani di Sumatra Barat. Mereka menggarap tanah hanya berdasarkan kebiasaan turun temurun dari orang tua mereka, sehingga mereka belum memahami benar apa hakekat dari pertanian konservasi, dan pengelolaan lahan terpadu. Mereka sulit untuk bisa mempercayai kalau tindakan pengelolaan yang mereka lakukan belum sesuai dengan kaidah konservasi. Mereka menganggap bahwa pengolahan tanah sampai halus dan membersihkan semua gulma serta bahan organik segar dari permukaan tanah adalah merupakan tindakan yang paling tepat. Pada hal kondisi demikian bisa berdampak negatif pada beberapa tahun ke depannya, terutama bagi kestabilan lingkungan.

Dampak ini semakin parah dengan pelaksanaan pertanian itu sendiri pada lahan marginal yang sifat fisikanya kurang menguntungkan, seperti Ultisols. Daerah Limau Manis lahannya didominasi oleh tanah ordo Ultisol. Sehingga, penduduknya bertani pada lahan yang sangat berbahaya untuk dibuka. Daerah ini dilalui oleh satu dari dua sungai besar yang melintasi kota Padang sebelum bermuara ke laut, yaitu Batang Kuranji. Sungai ini pada musim kemarau atau saat tidak hujan cukup dangkal, terbukti dengan terlihatnya batu-batuan di sungai tersebut dan bisa diseberangi oleh manusia ataupun ternak. Akan tetapi, pada saat hujan datang, sungai pernah meluap. Diantara bukti erosi yang cukup penting yaitu warna air sungai berubah drastis dari bening saat hari tidak hujan menjadi coklat kekuningan saat hujan turun. Hal ini membuktikan 


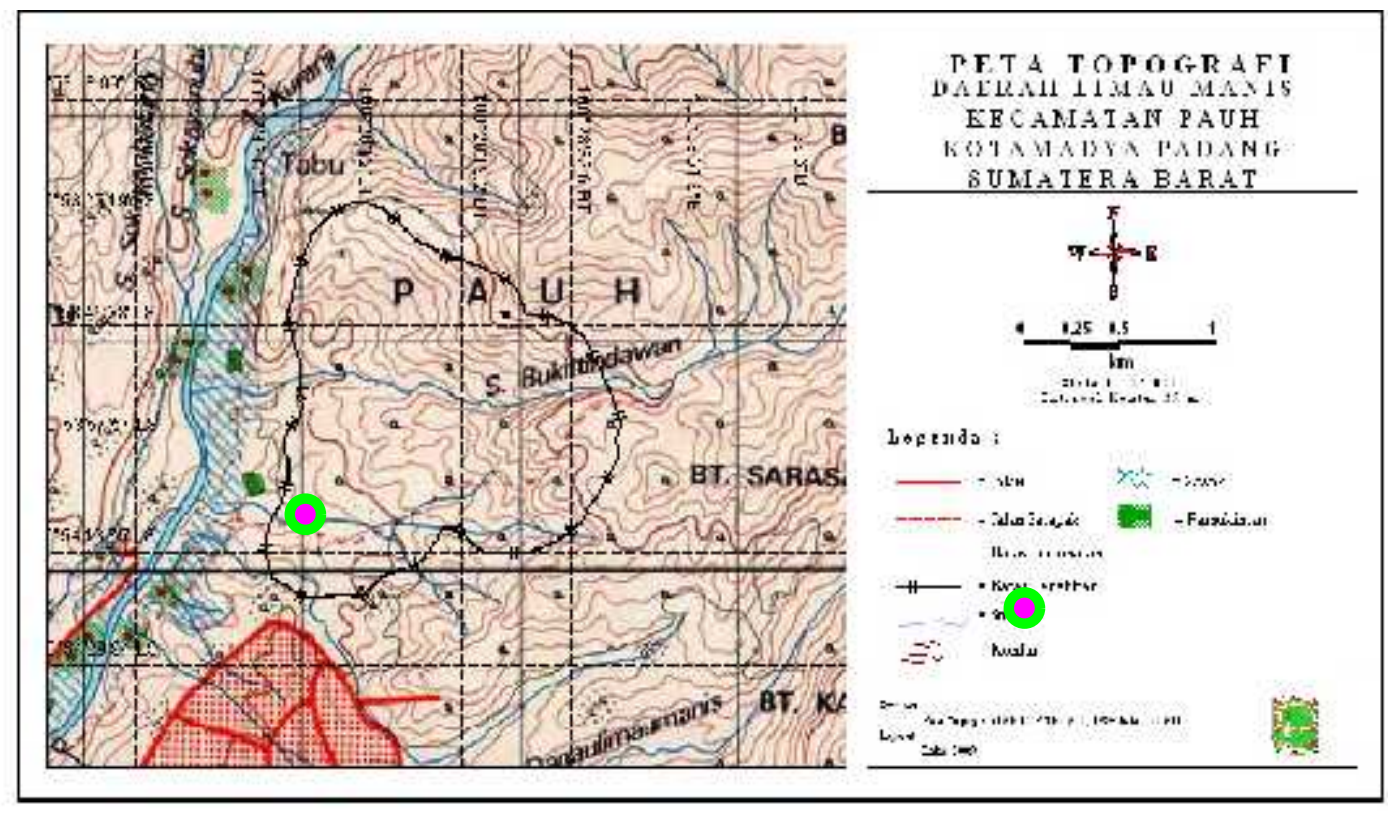

Gambar 1. Lokasi Penelitian di Limau Manis Kecamatan Pauh, Kodya Padang Sumatera Barat

bahwa daerah Limau Manis ini sudah mengalami pengikisan tanah, atau erosi yang bisa berakibat pada degradasi lahan bagi petani sendiri, juga pencemaran lingkungan serta banjir dan kekeringan bagi daerah alirannya, terutama bagi penduduk kota Padang.

\section{Sifat Fisik Tanah Awal Ultisol Limau Manis Sumbar}

Hasil analisis beberapa sifat fisika tanah Ultisol Limau Manis sebelum diberi perlakuan ditampilkan pada Tabel 1. Sifat fisika Ultisol yang ditampilkan disini yaitu tekstur, nilai bobot tanah persatuan volumenya (BV), nilai total ruang pori (TRP), dan nilai permeabilitas, kandungan BO, dan stabilitas aggregat tanah.

Ultisol Limau Manis pada lapisan $20 \mathrm{~cm}$ bagian atas mempunyai tekstur liat menurut segitiga tekstur USDA. Kandungan liat tanah lebih besar dari $70 \%$ baik pada ke tiga kelas lereng. Hal ini menandakan bahwa tanah-tanah tersebut sudah mengalami pelapukan lanjut. Tingkat pelapukan yang lanjut di daerah Limau Manis ini dipicu oleh kondisi iklim dengan curah hujan dan suhu yang tinggi. Tekstur tanah yang halus juga didapatkan pada Ultisol Sitiung Kabupaten Dharmasraya Sumbar, dengan kandungan liatnya mendekati 70\% (68.3\% liat) dan < 5\% kandungan pasir (Prasetyo et al., 2006).

Tekstur tanah akan mempengaruhi nilai BV suatu tanah selama faktor lainnya sama. Secara umum bobot volume (BV) tanah Ultisol limau Manis termasuk kriteria sedang, yaitu berkisar antara nilai $1 \mathrm{gcm}^{-3}$. Nilai BV tanah ultisol ini sangat ditentukan oleh kandungan liat yang tinggi. Liat mempunyai bobot persatuan volumenya yang lebih rendah dibanding pasir, walaupun pasir lebih poros, atau mempunyai persen pori makro yang lebih tinggi. Nilai BV tanah yang relatif rendah (sedang) ini meningkatkan total ruang pori atau rongga tanah. Akan tetapi, pori tanah didominasi oleh tekstur liat dan kandungan BO tanah rendah. Tingginya jumlah pori makroba menyebabkan laju permeabilitas tanahnya cendrung lambat. Sedangkan pori yang mampu melewatkan air yaitu pori makro atau pori geometri. Oleh sebab itu, tanah tanah ini menyerap sedikit air hujan yang jatuh kepermukaannya. Jika laju curah hujan lebih tinggi dari laju resapan atau infiltrasi, maka akan terjadi aliran permukaan (runoff).

Selanjutnya, kandungan BO tanah Ultisol Limau Manis umumnya berada pada kriteria rendah sampai sedang menurut LPT 
Tabel 1. Sifat fisika tanah awal Ultisol Limau Manis

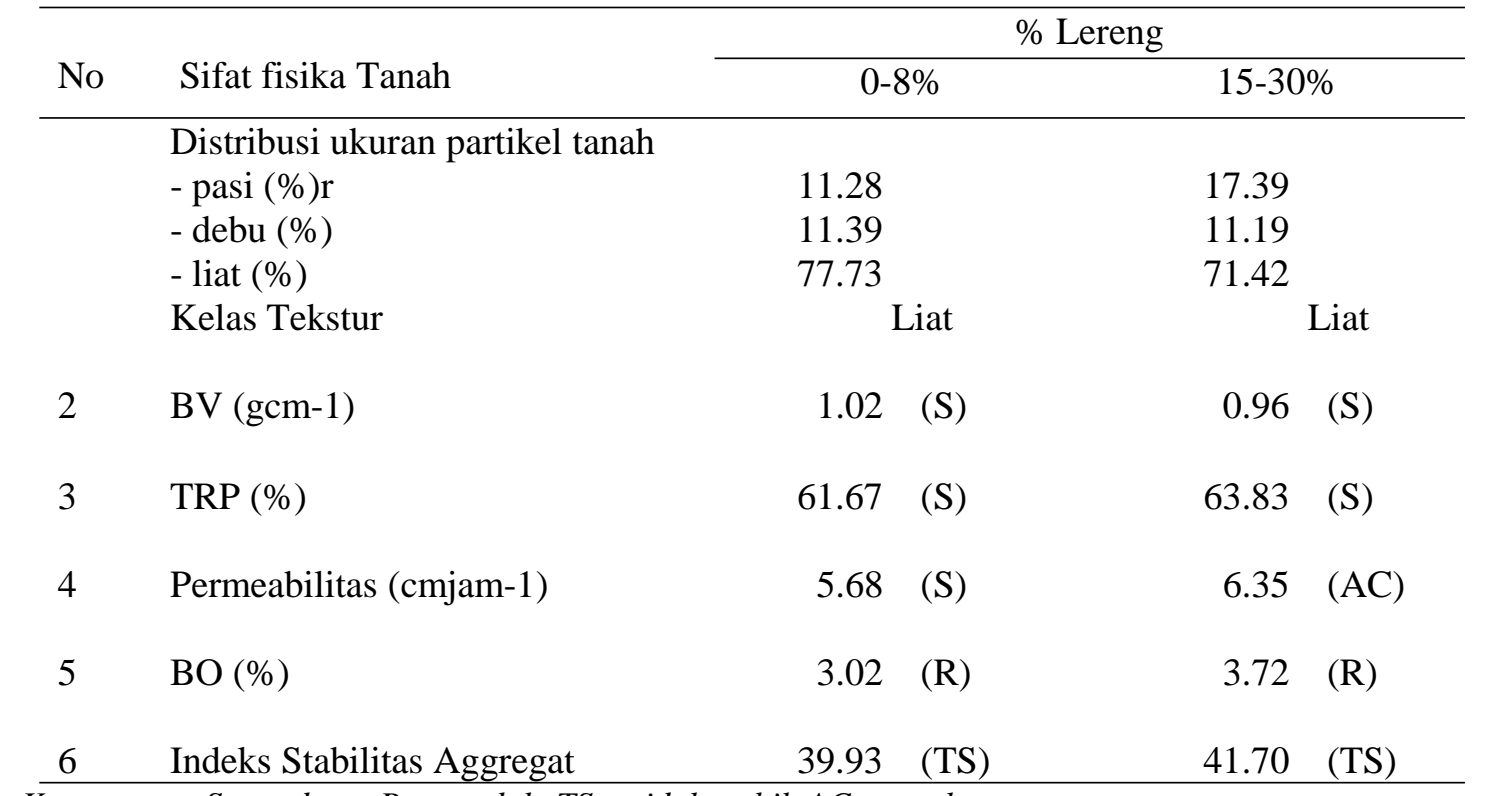

Keterangan: $S=$ sedang, $R=$ rendah, $T S=$ tidak stabil, $A C=$ agak cepat

(1979). Kandungan BO tanah penelitian yang tidak terlalu rendah pada lokasi penyampelan disebabkan oleh karena pengambilan sampel dilakukan pada lahan yang belum diolah, vegetasi yang tumbuh diatasnya selalu mensuplai BO pada tanahnya. Pada umumnya BO yang demikian akan mengalami pelapukan dan menyumbangkan humus atau BO pada tanah.

Kandungan BO tanah pada lapisan 0-20 $\mathrm{cm}$ sebagian besar berasal dari sumber yang ada di atas tanah (seperti daun, ranting, dahan, batang tanaman serta binatang), dan sedikit yang berasal dari dalam tanah (seperti exudat akar, akar yang mati, dan binatang tanah). Bila dilhat dari kecuraman lereng, ada kecendrungan peningkatan kandungan $\mathrm{BO}$ tanah dengan peningkatan kecuraman lereng. Hal ini sangat dimungkinkan oleh adanya hanyutan dari BO yang jatuh ke permukaan tanah secara horizontal dari daerah lain. Dengan adanya tanaman di lahan berlereng, maka hanyutan BO akan menyangkut dan menjadi sumber BO tanah. Dengan demikian, BO segar atau particulate yang dibawa oleh aliran permukaan akan menambah sumber BO yang ada di tempat dan bersama-sama melapuk menjadi BO tanah.

Kandungan BO tanah akan mempengaruhi stabilitas aggregat tanah. Dari Tabel 1 terlihat bahwa indeks stabilitas aggregat tanah Ultisol Limau Manis mengikuti pola yang sama dengan persen kandungan BO tanah. Yulnafatmawita (2006) melaporkan bahwa terdapat korelasi yang positif antara kandungan BO tanah dan stabilitas aggregat tanah Ultisol di Limau Manis ini. Menurut kriteria, aggreat tanah yang kurang dari 50 ini masih tergolong tidak stabil. Tanah yang kurang stabil ini akan menyebabkan aggegat tanah mudah hancur oleh energi luar seperti pengolahan tanah, tumbukan butir hujan, dan sebagainya. Kondisi tanah yang demikian sangat peka terhadap erosi.

3. Sifat Fisika Tanah Ultisol Limau Manis Setelah Panen

\section{a. Bahan Organik Tanah}

Kandungan BO, beberapa sifat fisika, dan stabilitas aggregat tanah Ultisol Limau Manis setelah aplikasi BO selama satu kali panen jagung ditampilkan pada Tabel 2. Dari data yang diperoleh terlihat bahwa tidak terlihat peningkatan BO yang nyata dari plot yang diberi dengan yang tidak diberi BO segar (Gambar 2). Hal ini mungkin disebabkan karena pada masa 4 bulan setelah aplikasi BO, belum semuanya BO tersebut yang melapuk, sehingga belum memberikan peningkatan yang signifikan 
Tabel 3. Sifat Fisika Ultisol Limau Manis yang diaplikasikan $20 \mathrm{~T} / \mathrm{Ha}$ BO setelah tanam jagung (Zea mays)

\begin{tabular}{|c|c|c|c|c|c|c|c|c|c|}
\hline Slope & Sumber BO & $\begin{array}{l}\text { Biomasa } \\
\text { ton } \text { ha }^{-1}\end{array}$ & $\begin{array}{c}\mathrm{BV} \\
\mathrm{g} \mathrm{cm}^{-3}\end{array}$ & \multicolumn{2}{|c|}{$\begin{array}{c}\text { TRP } \\
\% \\
\end{array}$} & $\begin{array}{c}\text { Permeabilitas } \\
\mathrm{cm} \mathrm{jam}^{-1}\end{array}$ & $\begin{array}{c}\mathrm{BO} \\
\%\end{array}$ & $\begin{array}{l}\% \text { Aggr } \\
>2.8 \mathrm{~mm}\end{array}$ & $\begin{array}{c}\text { Indeks } \\
\text { Stabilitas } \\
\text { Aggregate }\end{array}$ \\
\hline \multirow[t]{4}{*}{$0-8 \%$} & Tanpa PH & $1,36 \mathrm{c}$ & $0,87 \mathrm{~S}$ & 67,29 & $S$ & $98,15 \mathrm{SC}$ & $5,36 \mathrm{~S}$ & 61,38 & $49.74 \mathrm{~b}$ \\
\hline & Chromolaena & $2,05 \mathrm{bc}$ & $0,85 \mathrm{~S}$ & 68,02 & S & $103,21 \mathrm{SC}$ & $5,05 \mathrm{~S}$ & 61,74 & $57.31 \mathrm{a}$ \\
\hline & Gliricidia & $2,33 \mathrm{ab}$ & $0,84 \mathrm{~S}$ & 68,35 & $S$ & $93,74 \mathrm{SC}$ & $5,35 \mathrm{~S}$ & 69,17 & $49.76 \mathrm{~b}$ \\
\hline & Tithonia & 2,53 a & $0,85 \mathrm{~S}$ & 67,80 & S & $89,29 \mathrm{SC}$ & $5,98 \mathrm{~S}$ & 68,74 & $50.26 \mathrm{~b}$ \\
\hline \multirow[t]{4}{*}{$15-30 \%$} & Tanpa PH & $1,16 \mathrm{c}$ & $0,90 \mathrm{~S}$ & 65,86 & $S$ & $49,91 \mathrm{SC}$ & $4,39 \mathrm{~S}$ & 63,93 & $47.30 \mathrm{~b}$ \\
\hline & Chromolaena & $2,39 \mathrm{~b}$ & $0,86 \mathrm{~S}$ & 67,55 & $S$ & $56,98 \mathrm{SC}$ & $5,54 \mathrm{~S}$ & 63,89 & 55.79 a \\
\hline & Gliricidia & 2,56 a & $0,80 \mathrm{~S}$ & 69,89 & $S$ & $89,65 \mathrm{SC}$ & $6,51 \mathrm{~S}$ & 61,67 & $47.58 \mathrm{~b}$ \\
\hline & Tithonia & 2,88 a & $0,82 \mathrm{~S}$ & 68,94 & $S$ & $71,10 \mathrm{SC}$ & $6,07 \mathrm{~S}$ & 66,67 & $49.41 \mathrm{~b}$ \\
\hline
\end{tabular}





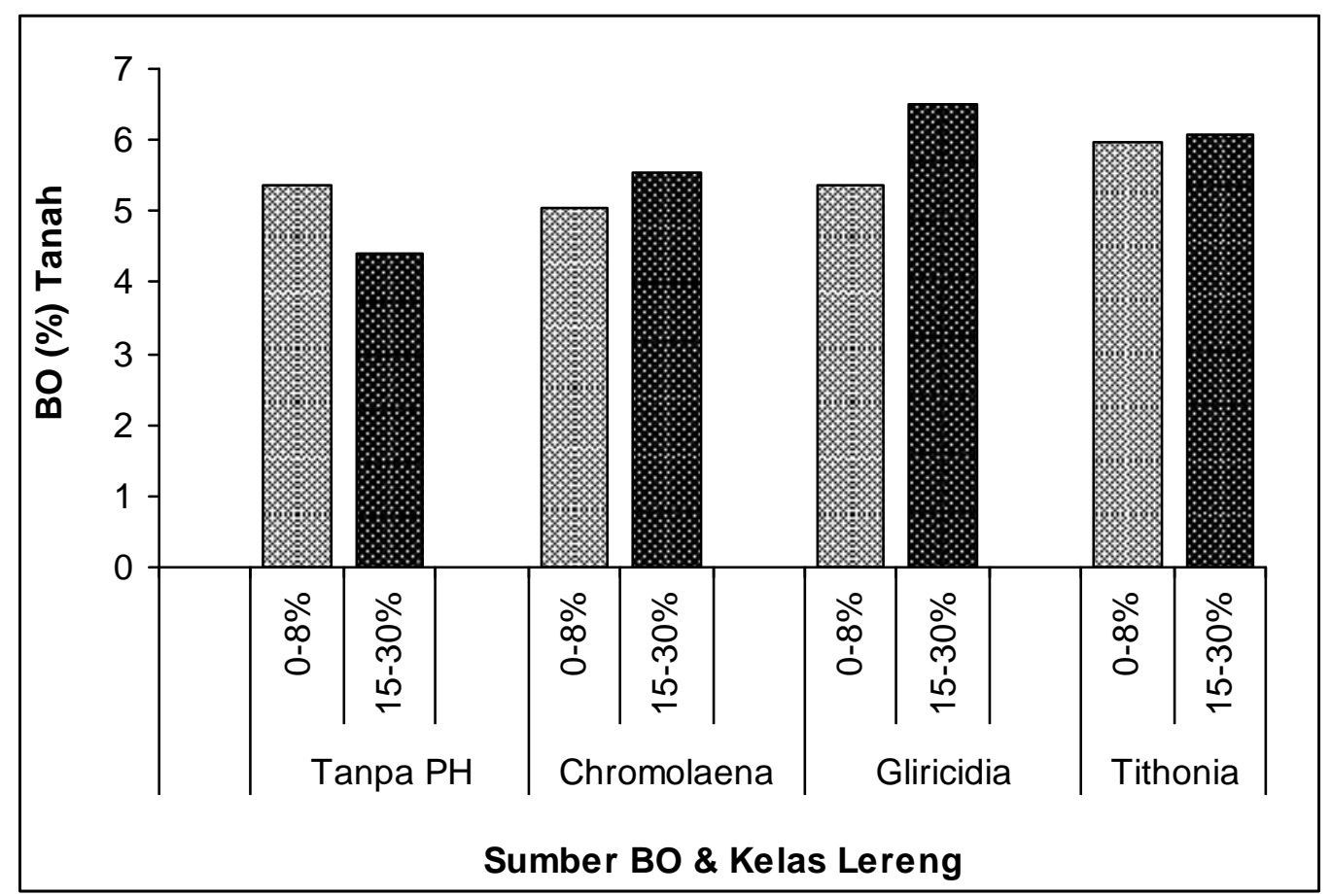

Gambar 2. Kandungan BO tanah Ultisol Limau Manis yang diaplikasikan 20 T/Ha BO setelah tanam jagung (Zea mays)

pada BO tanah. Namun, terlihat ada kecendrungan peningkatan kandungan $\mathrm{BO}$ tanah dari plot yang diaplikasikan dibanding yang tidak diberi pupuk hijau. Hal ini disebabkan karena bahan hijauan tanaman termasuk pada salah satu sumber BO tanah.

Jika dibandingkan dengan $\mathrm{BO}$ tanah awal Ultisol di Limau Manis ini yang termasuk kriteria rendah yaitu $\pm 3.0-3.7 \%$, maka penambahan BO sebanyak 20 t/ha pada tanah sebelum tanam jagung meningkatkan kandungan $\mathrm{BO}$ tanah sebanyak $\pm 1.2-3.7 \%$. Akan tetapi, bila dibandingkan dengan plot kontrol (tanpa penambahan BO), BO tanah hanya meningkat sekitar $0.67-2.34 \%$. Peningkatan BO tanah bukan saja akibat penambahan BO dalam bentuk bahan hijauan tanaman, tetapi dimungkinkan juga dipengaruhi faktor lain, seperti akibat pengolahan, aktifitas mikroba, dan sekresi akar tanaman.

Pengolahan tanah yang ditujukan untuk menggemburkan tanah dan menghilangkan gulma dari lahan pertanaman mempengaruhi kandungan $\mathrm{BO}$ tanah. Tanah yang diolah akan menjadi gembur, atau longgar sehingga bobot tanah persatuan volumenya menjadi kecil. Jika jumlah BO tanah yang dianalisis didasarkan pada berat tanah pada lapisan olah (kedalaman 0-20 cm), maka dengan jumlah BO yang sama dibandingkan dengan bobot tanah yang rendah, maka persen $\mathrm{BO}$ tanah akan meningkat dibandingkan dengan $\mathrm{BO}$ dari tanah yang tidak diolah atau tanah yang masih padat.

Di samping itu, yang lebih penting adalah jumlah mikroba yang meningkat berlipat ganda dengan adanya BO ditambahkan ke dalam tanah. Mikroba atau jasad hidup tanah akan lebih aktif mendekomposisi dan memperbanyak diri dengan penambahan BO ke dalam tanah. Ketika BO telah terdekomposisi semua, maka mikroba akan mati dan menyumbangkan BO ke dalam tanah. Dengan demikian, ketika proses dekomposisi selesai, penambahan BO tanah bukan saja berasal dari BO yang ditambahkan, tetapi juga dari mikroba yang mati.

Selanjutnya, tanaman yang sedang tumbuh juga bisa menyumbangkan BO ke dalam tanah akibat sekresi akar tanaman yang mengeluarkan asam-asam organik. Asam-asam organik bisa lansung menjadi 
BO tanah dan berasosiasi dengan tanah yang sangat bermanfaat bagi penyemenan atau penyatuan butir-butir tanah menjadi aggregat serta menstabilkannya. Tanahtanah yang ditanami akan mempunyai aggregat tanah yang lebih mantap, kecuali jika tanah diolah secara periodik dalam satu tahun.

Kandungan BO tanah berbeda tidak nyata pada berbagai lereng setelah satu kali musim tanam. Penambahan BO dalam bentuk bahan hijauan ke dalam tanah untuk tanaman semusim pada lahan datar sampai berlereng $25 \%$ memperlihatkan pengaruh yang relatif sama. Akan tetapi, jenis tanaman pupuk hijau memperlihatkan pengaruh yang berbeda terhadap kandungan BO dan stabilitas aggregat tanah. Pupuk hijau tithonia meningkatkan BO lebih tinggi dibanding jenis lainnya, terutama pada lereng kecil dari $15 \%$. Untuk lebih jelasnya, kandungan BO tanah masing-masing plot yang ditambahkan bahan hijauan ditampilkan pada Gambar 2.

Gambar 2 melukiskan kandungan BO tanah masing-masing lereng dalam plot yang diberi sumber BO yang berbeda. Kandungan BO tanah dari plot tithonia ratarata memberikan peningkatan kandungan BO yang lebih tinggi dari 2 bahan hijauan lainnya. Sedangkan plot tanpa penambahan BO masih meningkatkan kandungan BO tanah setelah $1 \times$ musim tanam jagung (4 bulan) dibanding tanah awalnya. Tetapi peningkatannya lebih kecil dari 3 perlakuan lainnya.

Peningkatan BO tanah yang lebih tinggi dengan penambahan bahan hijauan tithonia ke dalam tanah mungkin disebabkan oleh tithonia dalam waktu 4 bulan setelah applikasi (Mei-November 2008) sudah terdekomposisi sempurna, karena tithonia mempunyai kadar air dan kandungan $\mathrm{N}$ yang lebih tinggi dari bahan hijauan yang digunakan lainnya. Seperti yang dilaporkan Hakim dan Agustian (2003), tithonia mengandung $\mathrm{N}$ mencapai $3.5-4.0 \%$ dari bobot keringnya. Kandungan air tithonia yang digunakan dalam penelitian ini mencapai $480 \%$, sementara chromolaena $290 \%$ dan gliricidia $230 \%$. Tanaman yang mempunyai kandungan air tinggi lebih lunak dibanding yang berkadar air rendah, sehingga mudah lapuk. Di samping itu, kandungan $\mathrm{N}$ yang tinggi pada tithonia juga membantu mempercepat pelapukan, karena mikroba membutuhkan $\mathrm{N}$ yang banyak untuk memperbanyak dirinya. Oleh sebab itu, mikroba akan merombak tithonia lebih dulu dari yang lain.

b. B obot Volume, Total Ruang Pori, dan Permeabilitas Tanah

Kandungan $\quad \mathrm{BO}$ tanah mempengaruhi nilai bobot volume (BV) tanah. Nilai BV tanah secara umum menurun (sekitar 0.08-016 $\mathrm{gcm}^{-3}$ ) dengan peningkatan kandungan $\mathrm{BO}$ tanah. Hal ini disebabkan karena BO mampu merajut butir tunggal menjadi aggregat dan aggregat mikro menjadi aggregat makro yang mempunyai ruang antara aggregat tersebut. Semakin besar aggregat yang terbentuk, ruang pori yang bersebelahan dengan aggregat juga semakin besar. Di samping itu, BO sendiri mempunyai bobot yang rendah persatuan volumenya, sehingga penambahan BO menurunkan nilai BV tanah dibanding nilai $\mathrm{BV}$ tanah awalnya.

Penurunan nilai $\mathrm{BV}$ tanah dengan pemberian BO ini sesuai dengan yang dilaporkan oleh Yulnafatmawita (2006) bahwa tanah hutan dengan kandungan $\mathrm{BO}$ yang tinggi mempunyai nilai BV yang lebih rendah dibanding tanah yang sudah diladangkan untuk tanaman semusim. Akan tetapi, tidak terlihat perbedaan nilai BV tanah yang nyata antara tanah plot percobaan yang diberi dengan yang tidak diberi pupuk hijau setelah satu kali musim tanam. Hal ini disebabkan karena pada penelitian ini tanah sama-sama diolah. Pengolahan tanah dapat menggemburkan tanah, sehingga berat persatuan volume tanahnya menjadi rendah. Waktu kurang lebih 4 bulan dari pengolahan pertama sampai penyampelan tanah belum cukup untuk memadatkan tanah yang tidak diberi BO kembali. Oleh sebab itu, dalam waktu yang relatif pendek (4 bulan) ini pengaruh pengolahan lebih dominan dari pengaruh $\mathrm{BO}$ terhadap perubahan nilai BV tanah.

Penurunan nilai BV tanah menyebabkan peningkatan nilai TRP tanah. Dibanding tanah awal, peningkatan nilai TRP tanah berkisar antara 3.4-6.7\%. Hal ini disebabkan karena nilai BV berbanding terbalik dengan nilai TRP tanah. Nilai BV 
yang rendah mengindikasikan bahwa tanah tersebut longgar, atau dengan kata lain, tanah tersebut mempunyai banyak ruang yang tidak diisi padatan. Semakin banyak ruang, semakin rendah nilai BV tanah dan semakin tinggi nilai TRP tanah.

Nilai BV dan TRP tanah mempengaruhi laju pergerakan air dalam tanah pada kondisi jenuh atau dengan kata lain nilai permeabilitas tanah. Peningkatan nilai total ruang pori tanah, terutama ruang pori makro, akan mampu melewatkan air dalam jumlah yang banyak per satuan waktu. Dalam penelitian ini, penurunan BV dan peningkatan TRP mengakibatkan peningkatan laju permeabilitas tanah yang cukup tinggi (12.3-97.5 $\left.\mathrm{cmjam}^{-1}\right)$. Tanah dengan permeabilitas yang tinggi akan memberikan jumlah oksigen yang cukup bagi pernafasan akar tanaman dan juga bagi mikroba yang hidup di zona perakaran tersebut. Di samping itu, yang lebih penting adalah rendahnya kemungkinan air mengalir di permukaan tanah (run off) yang sering menyebabkan tanah tererosi, karena laju infiltrasi menjadi tinggi.

Seperti nilai BV, peningkatan total ruang pori dan permeabilitas tanah lebih dominan dipengaruhi oleh pengolahan tanah dari pada penambahan $\mathrm{BO}$ ke dalam tanah. Penambahan BO ke dalam tanah $20 \mathrm{~T} / \mathrm{Ha}$ sedalam $20 \mathrm{~cm}$ seperti yang dilakukan, hanya akan menyumbang $1 \%$ BO ke tanah jika telah melapuk sempurna. Kenyataannya, kandungan BO tanah meningkat sampai $3.96 \%$ pada plot yang diberi BO. Bahkan plot kontrol (yang tidak ditambah BO) juga meningkat mencapai 2.34\%. Oleh sebab itu, setelah 4 bulan appikasi BO dan pengolahan tanah, faktor pengolahan tanah lebih dominan mempengaruhi sifat fisika tanah Ultisol yang ditanami jagung ini.

\section{c. Indek Stabilitas Aggregat Tanah}

Stabilitas aggregat tanah yang merupakan kemampuan tanah menahan pengaruh luar yang akan mengubah bentuknya diuji di laboratorium dengan menggunakan ayakan kering dan basah. Ayakan basah menguji kestabilan aggregat tanah yang terbentuk, sedangkan \% aggregasi tanah diindikasikan dengan persentase berat diameter aggregat rata-rata dari hasil ayakan kering tanah. Indeks stabilitas dan persen aggregasi tanah setelah panen jagung ditampilkan pada Gambar 3.

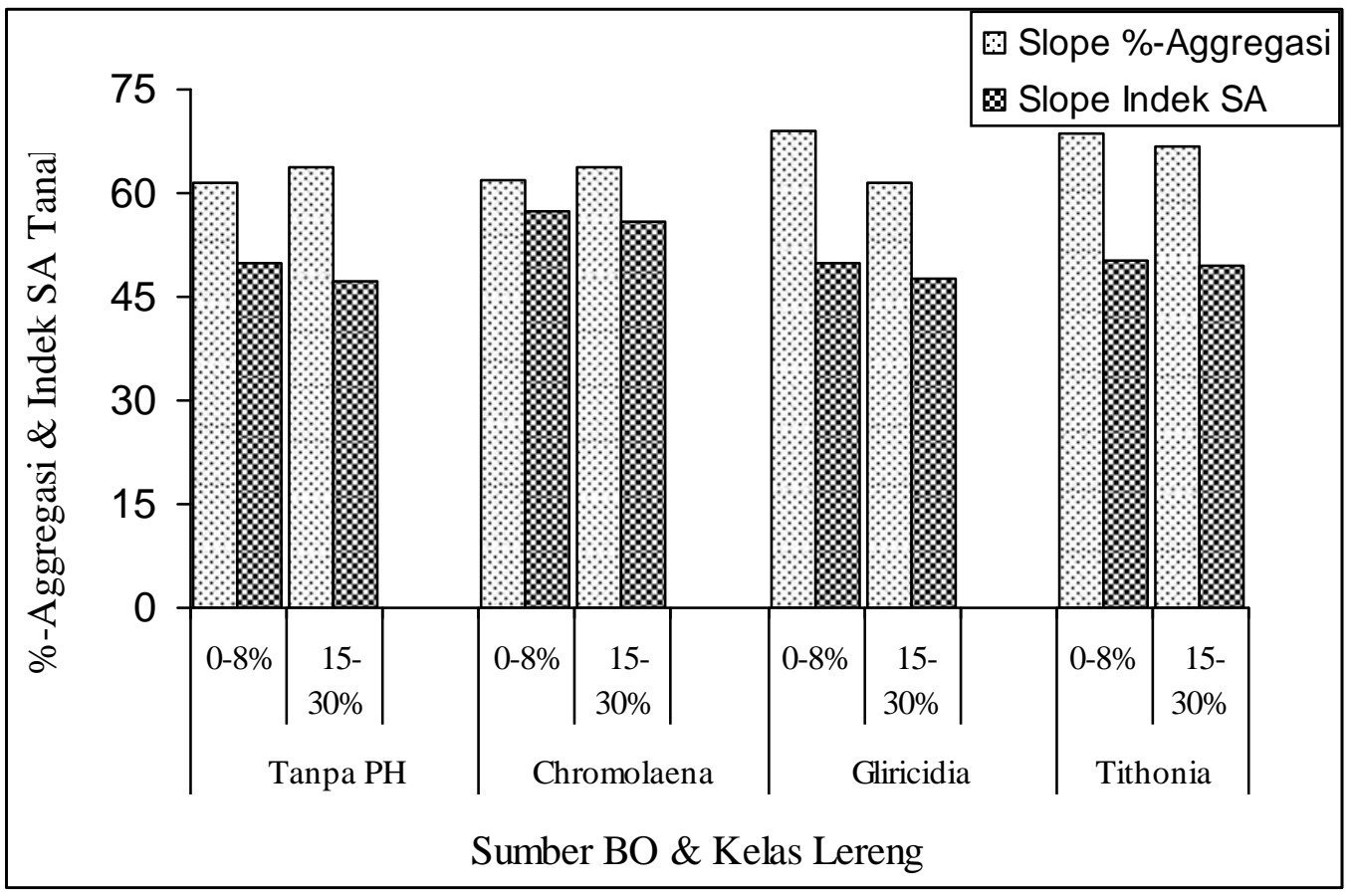

Gambar 3. Persen aggregasi dan indeks stabilitas aggregat (SA) Ultisol Limau Manis yang diaplikasikan $20 \mathrm{~T} / \mathrm{Ha} \mathrm{BO}$ setelah tanam jagung (Zea mays) 
Secara umum pada Gambar 3 dapat dilihat bahwa indeks stabilitas aggregat tanah lebih rendah dari nilai persentase aggregat tanah pada semua sumber BO dan kelas lereng. Hal ini berarti bahwa tidak semua aggregat yang terbentuk bersifat stabil, ada bahagian yang mudah hancur atau berubah bentuk dan ukurannya oleh adanya pengaruh luar. Jika dibandingkan antara indeks stabilitas aggregat dengan jumlah aggregat yang terbentuk atau persen aggregasi, maka dari ke 3 sumber BO, chromolaena memberikan persentase yang tertinggi (87-93\%). Hal ini mungkin disebabkan oleh kandungan bahan dalam chromolaena yang sepertinya ada perbedaan dari 2 sumber BO lain.

Bila dibandingkan dengan indeks stabilitas aggregat tanah awal, maka setelah penggunaan lahan untuk penanaman jagung satu kali musim tanam terjadi peningkatan stabilitas aggregat antara $14-26$ poin. Hal ini sejalan dengan peningkatan kandungan BO tanah seperti pada Tabel 2. Bahan organik berperan sebagai bahan perekat, panggabung, penyemen butir tunggal menjadi aggregat atau aggregat mikro menjadi makro, kemudian menstabilkannya. Sesuai dengan yang dilaporkan Yulnafatmawita (2006), ada korelasi positif antara kandungan $\mathrm{BO}$ dan stabilitas aggregat tanah.

Selanjutnya, bila dibandingkan dengan kandungan stabilitas aggregat tanah setelah panen dari plot yang tidak diberi $\mathrm{BO}$, maka peningkatan persen aggregasi dan stabilitas aggregat tanah tidak terlihat signifikan, atau hanya meningkat sekitar 4.58.5 poin. Jadi peningkatan stabilitas aggregat tanah setelah panen bukan sematamata oleh pemberian BO dalam bentuk bahan hijauan ke dalam tanah, tetapi juga oleh faktor lainnya. Faktor ini berkaitan erat dengan proses peningkatan $\mathrm{BO}$ seperti yang disampaikan pada bagian terdahulu, pada pembahasan $\mathrm{BO}$ tanah.

Indek stabilitas aggregat tanah setelah satu kali musim tanam dengan pemberian $20 \mathrm{~T}$ BO/Ha belum semuanya meningkatkan statusnya dari tidak stabil menjadi stabil, kecuali plot yang diberi BO chromolaena. Stabilitas aggregat tanah yang diberi BO chromolaena pada semua kelas lereng sudah berubah menjadi stabil, kemudian diikuti oleh tithonia, dan kemudian gliricidia. Masa 4 bulan setelah aplikasi BO memungkinkan perubahan stabilitas aggregat tanah belum signifikan. Pada waktu yang relatif singkat ini, dari pengamatan di lapangan, belum semua BO terurai sempurna dan menyumbangkannya menjadi BO tanah.

\section{d. Produksi J agung}

Produksi biomasa tanaman jagung yang diaplikasi dengan tiga macam sumber BO pada dua kelas lereng ditampilkan pada Gambar 4. Pada gambar 4 terlihat bahwa penambahan BO meningkatkan biomasa tanaman jagung secara nyata pada setiap kelas lereng. Hal ini menunjukkan bahwa BO yang ditambahkan dalam bentuk bahan hijauan tanaman mampu memperbaiki kondisi zona perakaran tanaman sehingga pertumbuhan tanaman menjadi lebih baik dan produksi biomasanya lebih tinggi. Tanah sebagai media tanam dengan sifat fisik yang baik, seperti tanah cukup gembur (BV lebih rendah), aerase dan drainase lancar, maka akar tanaman bisa berkembang dngan leluasa di dalam tanah dan mampu menembus bagian-bagian tanah yang menyimpan unsur hara. Dengan air yang cukup tersedia dan dibantu oleh aerase yang baik untuk menyediakan $\mathrm{O} 2$ yang dibutuhkan akar bagi pernafasannya menyebabkan akar mampu menyerap hara yang ada di dalam tanah secara optimal. Kondisi demikian menciptakan pertumbuhan tanaman yang maksimal dan produksi yang tinggi, selama hara cukup tersedia di dalam tanah.

Diantara tiga jenis sumber BO yang diaplikasikan, pengaruhnya berbeda bagi pertumbuhan tanaman jagung. Tanaman jagung memberikan produksi rata-rata tertinggi dari plot yang diberi titonia, yaitu 2.62 ton/ha dan 2.88 ton/ha untuk lereng 0$8 \%$ dan $15-30 \%$, secara berturut-turut. Tingginya produksi jagung pada plot titonia, di samping perbaikan sifat fisik tanah di zona perakarannya, juga mungkin disebabkan oleh sumbangan $\mathrm{N}$ yang tinggi dari titonia. Menurut Hakim dan Agustian (2003) dan Gusnidar (2007) kandungan N titonia bisa mencapai $4 \%$ dari bobot keringnya. 


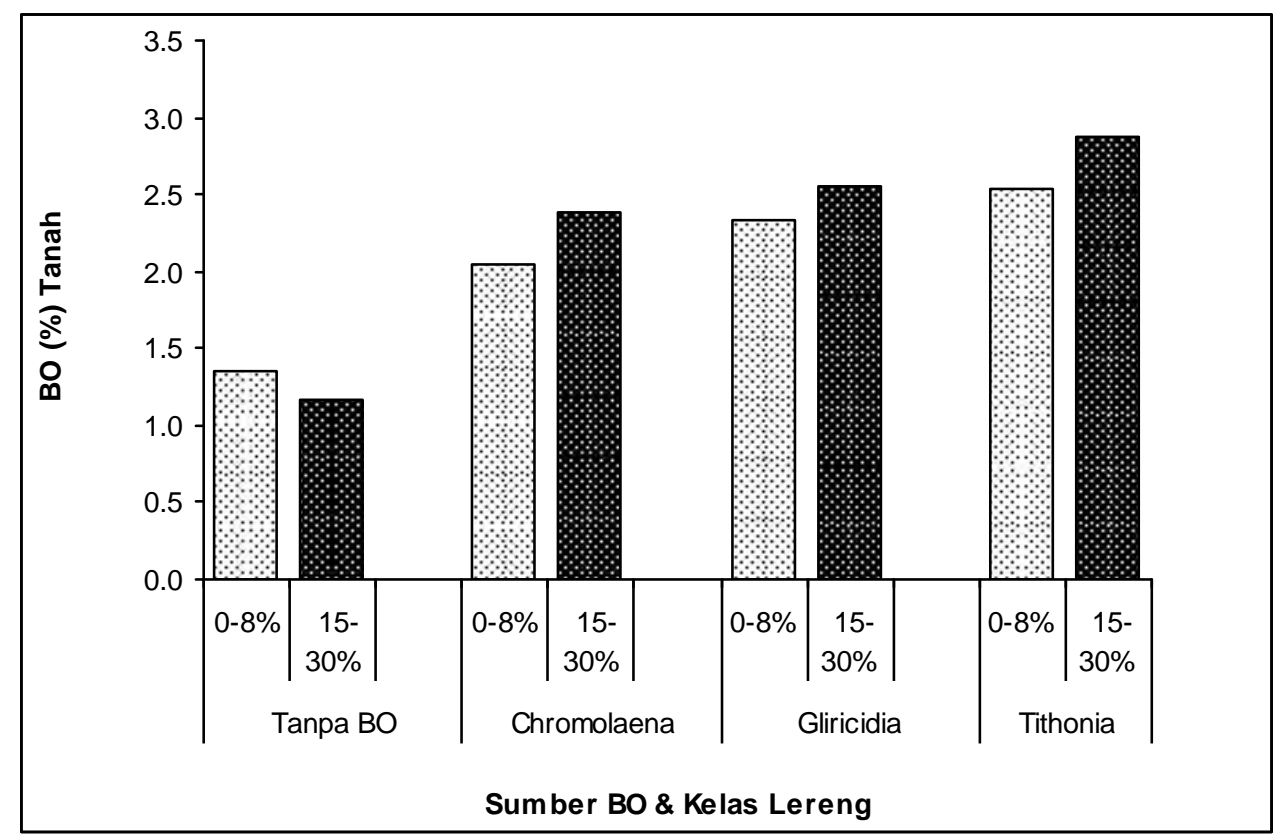

Gambar 4. Produksi biomasa jagung pada Ultisol Limau Manis yang diaplikasikan 20 T BO/Ha setelah satu kali musim tanam jagung

Gambar 4 juga melukiskan bahwa produksi biomasa jagung pada lereng $0-8 \%$ cendrung lebih rendah dari lereng $15-30 \%$ pada plot yang diberi BO, tetapi sebaliknya diperoleh dari plot yang tidak diberi BO. Tingginya produksi tanaman pada lereng yang lebih curam (15-30\%) sejalan dengan peningkatan $\mathrm{BO}$ dan SA yang lebih tinggi dibanding pada lereng $0-8 \%$. Akan tetapi, hal ini bertolak belakang dengan ketentuan umum, seharusnya pada lereng yang lebih curam kandungan $\mathrm{BO}$ tanah dan SA akan lebih rendah dari lahan yang relatif datar. Pada kondisi lahan penelitian di Limau Manis, kenyataann ini sangat ditentukan oleh vegetasi yang tumbuh sebelumnya. Karena sebelum ini tanah belum pernah diolah selama puluhan tahun, tetapi ditutupi oleh semak belukar, maka kondisi awal tanah belum berbeda antara yang datar dan berlereng.

\section{KESIMPULAN DAN SARAN}

Dari hasil penelitian yang dilakukan baik terhadap identifikasi sifat fisika tanah di Limau Manis dan pertumbuhan tanaman jagung dengan mengapikasikan 20T/Ha BO ke dalam tanah, maka dapat disimpulkan bahwa:

1. Sifat fisika tanah Utisol Limau Manis yang diteliti mempunyai tekstur liat, BV sedang sampai agak tinggi, kandungan $\mathrm{BO}$ dan permeabilitas umumnya rendah, TRP rendah sampai sedang, dan didominasi oleh aggregat $<2.8 \mathrm{~mm}$.

2. Aplikasi 3 jenis sumber BO (Titonia diversifolia, Chromolaena odorata, dan Gliricidia sepium) meningkatkan kandungan BO (antara 0.67-2.34\%), indeks stabilitas aggregat tanah (antara 0.02-8.49 poin), serta produksi tanaman (antara 0.63-1.72 T/Ha).

3. Kandungan BO dan stabilitas aggregat yang terbaik serta produksi tanaman tertinggi untuk tanaman jagung diperoleh dari plot yang diaplikasi dengan titonia

4. Terjadi perbaikan sifat fisika tanah Ultisol Limau Manis lainnya seperti $\mathrm{BV}$, TRP, dan permeabilitas dengan aplikasi bahan hijauan tanaman sebagai sumber BO tanah. 
Berdasarkan kesimpulan diatas, maka disarankan untuk menggunakan bahan hijauan titonia untuk tanaman jagung. Akan tetapi, untuk melihat efektifitas ketiga jenis sumber BO tersebut bagi peningkatan stabilitas aggregat maka penelitian ini perlu dilanjutkan untuk beberapa kali penanaman.

\section{UCAPAN TERIMA KASIH}

Pada kesempatan ini penulis mengucapkan terima kasih kepada DP2M Dikti yang telah membiayai penelitian ini melalui dana Hibah Bersaing tahun 2008. Terima kasih juga penulis sampaikan kepada semua pihak yang membantu.

\section{DAFTAR PUSTAKA}

Burhan W., Yulnafatmawita, dan Hakim, N. 1996. Seleksi tanaman pupuk hijau di lahan marginal berpasir Air Tawar Padang. Prosiding Seminar BKS-PTN Barat 1997, Padang.

Gusnidar. 2007. Pemanfaatan Tithonia diversifolia untuk menghemat pemupukan N,P, dan $\mathrm{K}$ tanaman padi sawah intensifikasi. JurusanTanah Fakultas Pertanian Unand. Padang.

Hakim, N. dan Agustian. 2005. Pemanfaatan titonia sebagai sumber bahan organic dan unsur hara untuk tanaman jagung pada Ultisol. Laporan Kemajuan Penelitian Tahun III Hibah Bersaing. Proyek Peningkatan Penelitian Perguruan Tinggi DP3M Ditjen Dikti. Unand Padang.

Hakim, N. 2006. Pengelolaan Kesuburan Tanah masam dengan Teknologi pengapuran Terpadu. Andalas University Press. Padang.
Hakim, N., Darfis, I., dan Arfania, L. 2007. Efek sisa dan tambahan titonia terhadap sifat kimia Ultisols dan hasil tanaman jagung pada musim tanam ke tiga. Laporan Hibah Penelitian SP-4 J urusan Tanah Fak. Pertanian U nand Padang.

Jamilah. 2006. Potensi gulma C.odorata sebagai pupuk dibandingkan $G$.sepium alternatif yang diberi CMA pada lahan marginal. Disertase Doctor Facultas Pasca Sarjana Universitas Andalas Padang.

Prasetyo, T. B., Ruhaimah, Wardhana, S. A. 2006. Pengaruh pengelolaan air terhadap konsentrasi besi $(\mathrm{Fe})$ pada sawah bukaan baru. J. Solum Vol III(1):8-18.

Rasyidin, A 1994. The method for measuring rates of weathering and rates of soil formation in watershed. Disertase. Tottory Univ. Japan, $110 \mathrm{p}$.

Yulnafatmawita. 2006. Hubungn antara status C-organik tanah dan stabilitas aggregate Ultisol Limau Manis akibat perubahan penggunaan lahan. Prosiding Seminar BKS Barat di Jambi 26-28 April

Yulnafatmawita, Saidi, A., dan Gusnidar. 2008. Upaya perbaikan stabilitas aggregat tanah melalui peningkatan karbon organik pada lahan marginal di daerah tropis super basah Sumatra Barat. Laporan Penelitian HIBER Tahun I (2008). DP3M Dirjen Dikti. 